\title{
Leptin and Leptin Receptor are Expressed only in Clear Cells of Rat Epididymis Epithelia
}

\author{
La Leptina y el Receptor de Leptina se Expresan Solamente \\ en Células Claras del Epitelio Epidídimario de Rata
}

Flavia Meireles Gombar \& Cristiane da Fonte Ramos

GOMBAR, M. F. \& RAMOS, F. C. Leptin and leptin receptor are expressed only in clear cells of rat epididymis epithelia. Int. J. Morphol., 35(4):1303-1308, 2017.

SUMMARY: Leptin is a 16 kilodaltons hormone secreted by adipose tissue and in the past few years it has been related to the reproductive system regulation. Leptin and its receptor (OBR) have been described in several reproductive organs and in different species but, in epididymis, there is still a lack of information. The aim of this work is to establish if leptin and its receptor are present on epididymis and where the production is occurring. At mRNA level the cauda portion showed a high expression of leptin $(p<0.025)$ and OBRa $(\mathrm{p}<0.002)$ while at protein level the OBR expression was lower in cauda region $(\mathrm{p}<0.025)$ and leptin was not detected. The ratio between OBRa and OBRb was higher in both regions despite its total amount. By immunohistochemistry leptin and OBR were detected on epididymis epithelia, restricted to clear cells (CC). After efferent duct ligation (EDL) a decrease on leptin staining on CC was observed, suggesting that despite of epididymis production, most of leptin source may probably come from testis. Our results show that leptin and OBR, both mRNA and protein, are present on epididymis and exclusively in CC, suggesting that this tissue is responsive to the hormone and may have an important role on $\mathrm{CC}$ regulation.

KEY WORDS: Epididymis; Clear cell; Leptin; OBR.

\section{INTRODUCTION}

Leptin is a 16 kilodaltons hormone secreted by adipose tissue (Zhang et al. 1994) which six isoforms of its receptor have already been reported as short (OBRa, OBRc, OBRd, OBRe and OBRf) and long (OBRb) (Tartaglia, 1997). This hormone is related to energy balance and food intake and its function is well established (Havel, 2000). However, in the past few years the presence of both leptin protein and messenger RNA (mRNA) have been described in different reproductive tissues (da Silveira Cavalcante et al., 2009; Rago et al., 2009; Alves-Pereira et al., 2012; Gombar \& Ramos, 2013). The outcome that correlates leptin and reproduction are new concerning epididymis.

Testis is commonly the reproductive tissue related to fertility regulation, modulation and contraception (TenaSempere \& Barreiro, 2002; Lee \& Cheng, 2004). However, reports of no spontaneous pregnancy concerning healthy couples with idiopathic infertility (Guo et al., 2014) lead to other way such as post testicular factors. Epididymis is a very specialized organ divided in 4 major regions (initial segment, caput, corpus and cauda) and 5 different cells types (principal, clear, halo, basal and apical cells) (Cornwall, 2009). Each region has the potential to secrete and reabsorb different types and amounts of proteins (Liu et al., 2015), working as an independent environment, having an effect on spermatozoa maturation (Yuan et al., 2006) and epithelia local regulation (Shum et al., 2011).

Contrary to what is known on reproductive tissues, there are a few reports showing the presence of leptin and its receptors on epididymis and it is concerned to pig and lizard models only (Putti et al., 2009; Rago et al., 2009). As the rodent is largely used as a research model and there is still a lack of information on leptin localization and function in the epididymis, this study was designed to evaluate the hypothesis that leptin and its receptors are present on rat epididymis, and furthermore if this organ is a site for leptin synthesis.

Laboratory of Morphometry, Metabolism and Cardiovascular Disease, Biomedical Center, Institute of Biology, State University of Rio de Janeiro, Brazil. This work was supported by the agency FAPERJ (Rio de Janeiro State Foundation for Scientific Research, www.faperj.br) by the grant number E-26/ $1116.48 / 2011$. 


\section{MATERIAL AND METHOD}

All experimental procedures were developed at the Laboratory of Morphometry, Metabolism and Cardiovascular disease (LMMC) of Anatomy Department in the State University of Rio de Janeiro. The study was approved by an Institutional Committee for Ethics in Animal Experimentation and were conducted in accordance with The Guide for the Care and Use of Laboratory Animals.

Experimental Design. Six control adult male Wistar rats, 3 months old, were housed in groups of up to three/ cage under conditions of controlled temperature and humidity and circadian cycle (12-h light/12-h dark photoperiod). All animals had free access to pelleted standart rodent chow (Nuvital; Curitiba, PR, Brazil) and tap water until the time of euthanasia by $\mathrm{CO}_{2}$ inhalation. At this moment, one epididymis of each animal were dissected and stored at $-80^{\circ} \mathrm{C}$ until analysis and the other one was placed in $4 \%$ paraphormaldehyde.

Efferent duct ligation. Unilateral efferent duct ligation (EDL) surgery were performed to prevent factors and spermatozoa from testes to enter the epididymis, as described previously (Palladino \& Hinton, 1994). Six rats were anesthetized with pentobarbital $(50 \mathrm{mg} / \mathrm{kg})$. The testis was accessed through a low midline incision, efferent ducts were exposed and a needle leading a 4-0 nylon suture was passed around the ducts. Care was taken to avoid damage to nearby blood vessels. The suture was tied tightly around the efferent ducts and the testes and epididymis were placed back into the abdomen. The surgical site was closed using nylon sutures and after fifteen days the rats were killed and both epididymis removed and placed into buffered formalin to proceed immunohistochemistry analysis.

Western Blotting. Six epididymis were dissected in caput and cauda, minced and homogenized in ice-cold lyses buffer (50 $\mathrm{mM}$ Tris, $150 \mathrm{mM} \mathrm{NaCl}, 0.1 \%$ SDS, NP-40 \%, EDTA $1 \mathrm{mM}$, $\mathrm{Na} 3 \mathrm{VO} 41 \mathrm{mM}, \mathrm{NaF} 1 \mathrm{mM}$ and $1 \mathrm{mM}$ PMSF, pH 7.8). Protein concentration was determined using the BCATM protein assay kit (Thermo Scientific) according to manufacturer's instructions. After denaturation, samples were subjected to 10 $\%$ SDS-PAGE, subsequently transferred to polyvinylidene (PVDF) membranes, blocked with $5 \%$ BSA in Tris- buffered saline (TBS $20 \mathrm{mM}$ Tris- $\mathrm{HCl}, 500 \mathrm{mM} \mathrm{NaCl}, \mathrm{pH}$ 7.6) and incubated with primary antibodies overnight. The primary antibodies used were anti-Bactin (1:1000; sc81178; Santa Cruz Biotechnology), anti-OBR (1:500; ab5593; Abcam) and antiLeptin (1:500; L3410; Sigma-Aldrich). Subsequently, the membranes were incubated with the appropriate secondary antibody. The membrane was developed using enhanced chemiluminescence kit (ECL, Millipore) and the images of optical densities of immunoreactive bands were obtained with the Bio-Rad Molecular Imaging ChemiDoc XRS System (BioRad) and quantified using Image J software, version 1.49i (NIH, imagej.nih.gov/ij, USA. The blots were stripped and reprobed for Bactin as a loading control to normalize the blot data.

RNA Extraction and Real time RT-PCR. Six epididymis were dissected in caput and cauda, and then used for evaluation of total RNA and Real time RT-PCR. Briefly, tissues were minced and homogenized in $1 \mathrm{ml}$ of Trizol reagent (Invitrogen) per 50-100 mg of tissue. Then, RNA was extracted by a phenol/ chloroform solution and precipitated by isopropyl alcohol. After washing with $75 \%$ ethanol, the RNA was dried and dissolved with Mili-Q water. The quality of RNA samples was verified by determination of the ratio $260 \mathrm{~nm} / 280 \mathrm{~nm}$. The samples were stored at $-80{ }^{\circ} \mathrm{C}$ until utilization. All RNA samples were rid of contaminating DNA by using DNA-free reagents. One mg of RNA was used in the cDNA reaction using Oligo-dT (Invitrogen) and the superscript III cDNA synthesis system (Invitrogen) according to the manufacturer's protocol. The Real Time PCR amplification was performed using $2 \mathrm{~mL}$ of cDNA with a concentration of $0.1 \mu \mathrm{g} / \mu 1$, with specific primers for OBRa sense (5'gatttcttgggacagccaaa-3') antisense (3'-ctcttgctcctcacctggac5'); OBRb sense (5'-ggttggatgagcttttggaa-3') antisense (3'tcctggaggatcctgatgtc-5'); B-actin sense ( $5^{\prime}$-ctccggcatgtgcaa3') antisense (3'- cccaccatcacaccct-5'). SyBR Green reagent (Invitrogen) was used in a final volume of $20 \mathrm{~mL}$. The reactions were performed in triplicate.

Immunohistochemistry. For immunohistochemistry analysis, six epididymis from control group and twelve epididymis from efferent duct ligation (EDL) group were fixed in $10 \%$ buffered formalin, processed and embedded in paraffin. Deparaffined sections of epididymis from both groups were hydrated, treated with citrate buffer ( $\mathrm{pH} \mathrm{6.0)}$ ) for $20 \mathrm{~min}$ at $60{ }^{\circ} \mathrm{C}$ and then 30 min at room temperature for antigen retrieval, treated with 3 $\%$ hydrogen peroxide solution in methanol for $10 \mathrm{~min}$ to block endogenous peroxidase activity. These steps were followed by washing the sections in PBS and subsequently incubating $20 \mathrm{~min}$ at room temperature with $1 \% \mathrm{PBS} / \mathrm{BSA}$ solution to block unspecific binding and incubated overnight at $4{ }^{\circ} \mathrm{C}$ with leptin antibody (1:50; L3410; Sigma-Aldrich) and OBR (1:200; ab5593; Abcam), both in $1 \%$ PBS/ BSA. Sections were then washed in PBS and incubated at room temperature for 30 min with biotinylated secondary antibody followed by incubation at room temperature for $30 \mathrm{~min}$ with streptavidinperoxidase conjugate (Histostain-Plus Kit, Invitrogen). Sections were washed in PBS and then revealed with liquid diaminobenzidine (Histostain-Plus Kit, Invitrogen).

Statistical Analysis. All results are expressed as mean \pm SEM. Statistical analysis was performed by Student's-t - test. Values of $\mathrm{p}<0.05$ were considered significant. 


\section{RESULTS}

Western blot technique was used to evaluate the expression of leptin and its receptor in the epididymis of control animals. While OBR was detected in both caput and cauda portions, the protein itself was detected only on epididymis caput. In relation to OBR expression, there was a significant reduction on epididymis cauda compared to caput (p<0.025) (Fig. 1).
Real time PCR was used to evaluate the mRNA expression of leptin and the OBRa and OBRb isoforms in the caput and cauda of epididymis. OBRa $(\mathrm{p}<0.002)$ and leptin $(\mathrm{p}<0.025)$ expression were significantly higher in the cauda compared to caput region (Fig. 2a, c). No difference was observed regarding OBRb gene expression between the two regions (Fig. 2b).
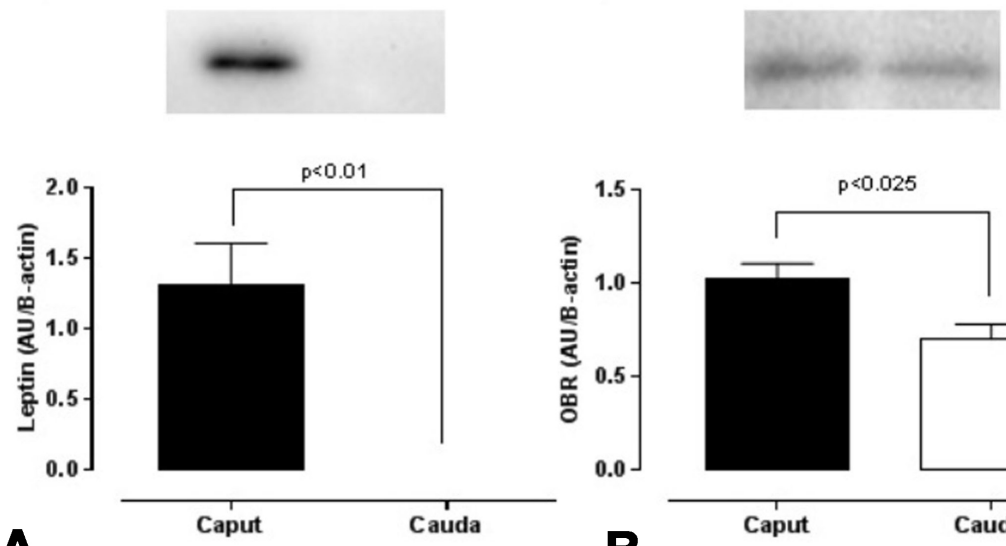

$$
\text { A }
$$

Fig. 1. Protein expression of leptin (a) and OBR (b) on epididymis caput and cauda of control adult Wistar rats. Values are given as mean \pm SEM of six animals per group.
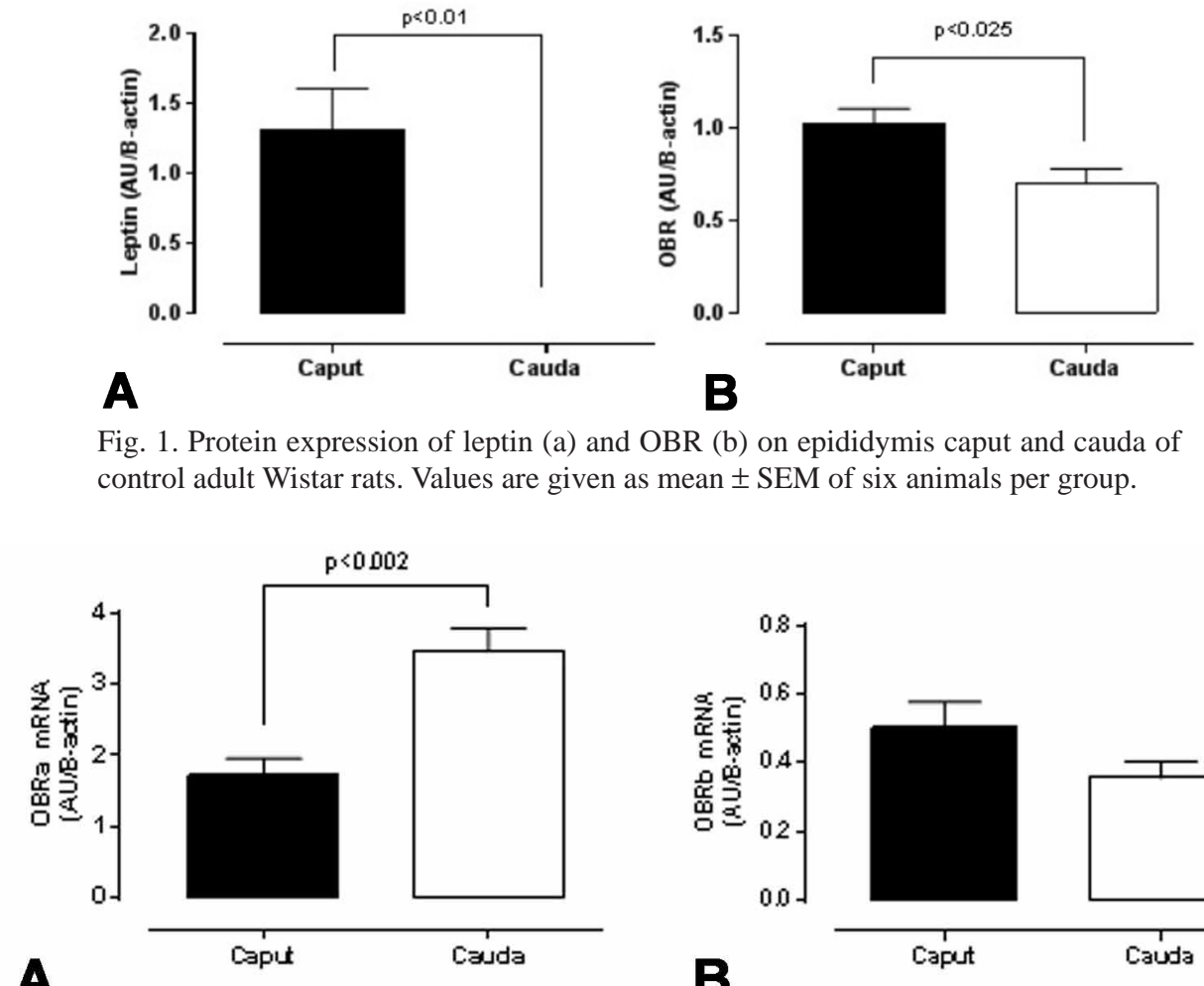

B
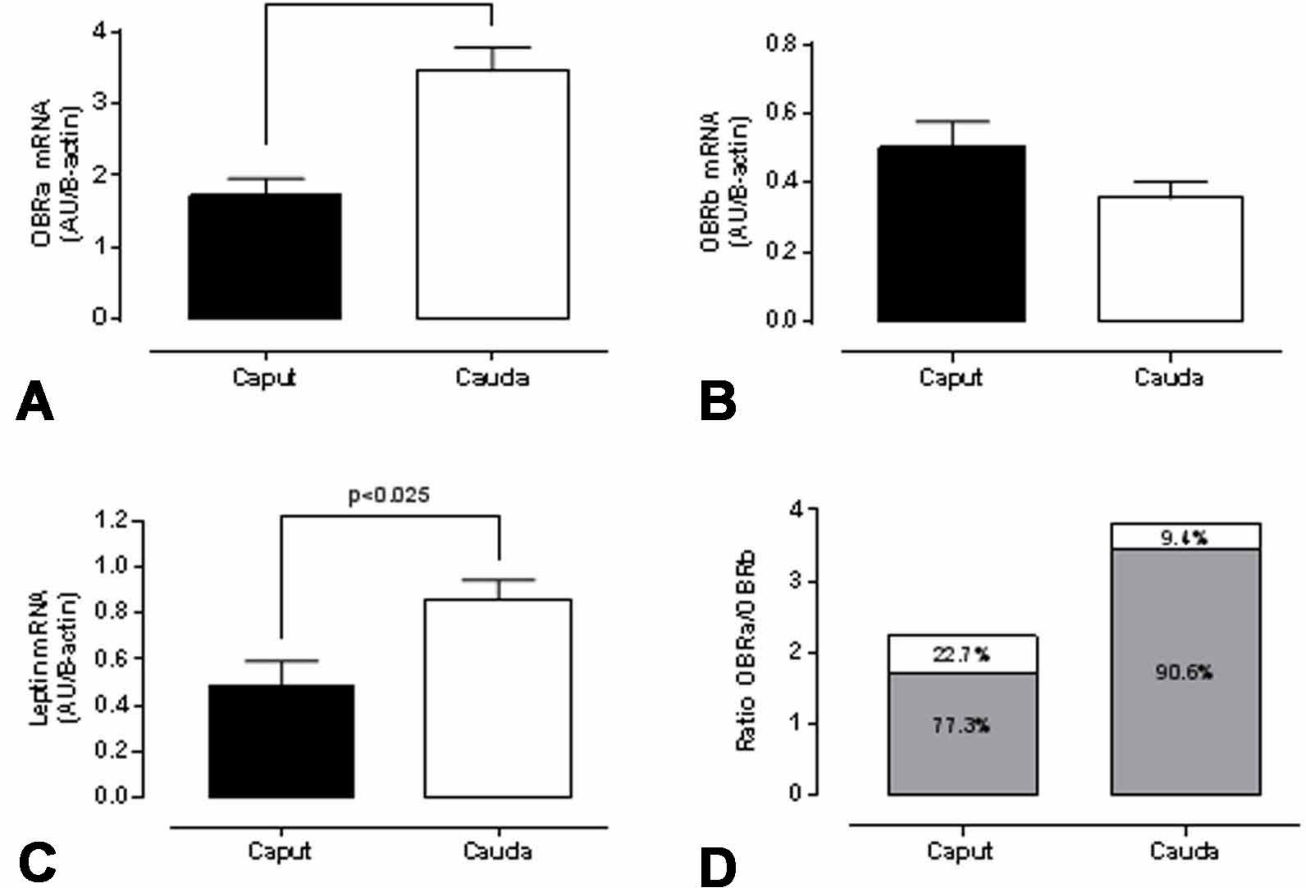

Fig. 2. mRNA expression of OBRa (a), OBRb (b) and leptin (c) on epididymis of control adult Wistar rats. OBRa/ OBRb ratio in caput and cauda is shown in letter d. OBRa (gray) and OBRb (white). Values are given as mean \pm SEM of six animals per group. 


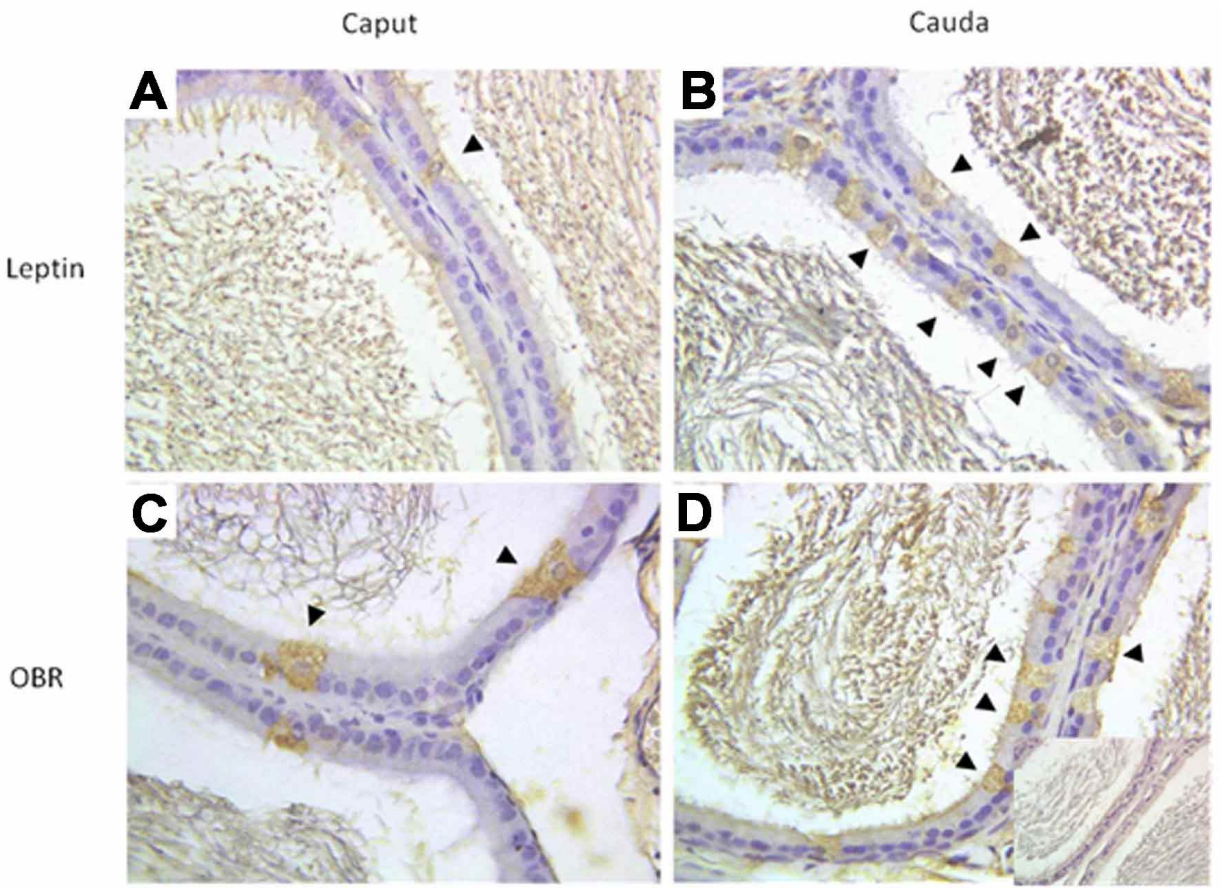

Fig. 3. Immunohistochemical staining for leptin and OBR on caput and cauda portions of epididymis. The arrowheads show clear cells stained on epididymis epithelia. The insert shows negative control. Magnification X 200.
Caput
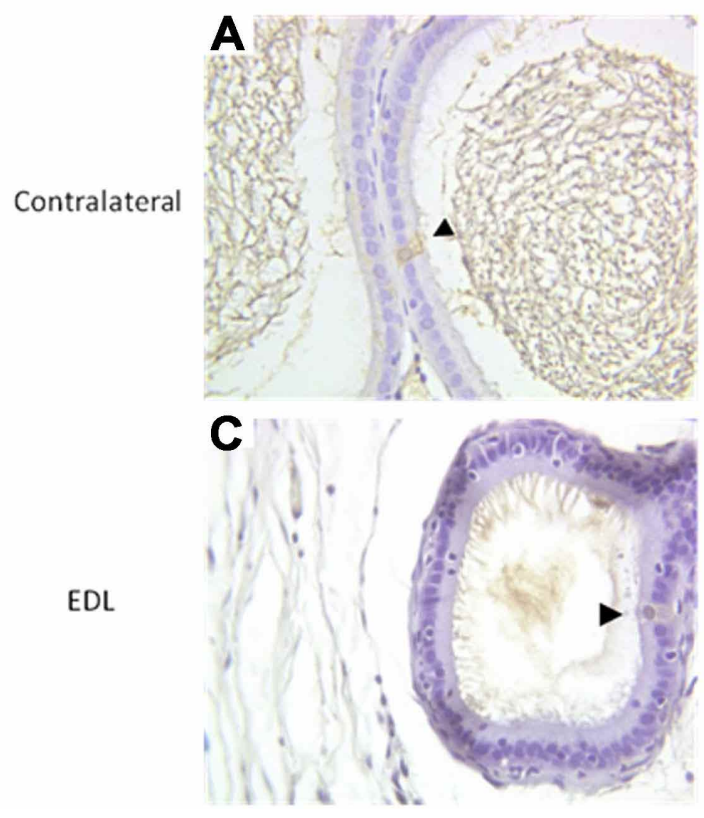

Cauda
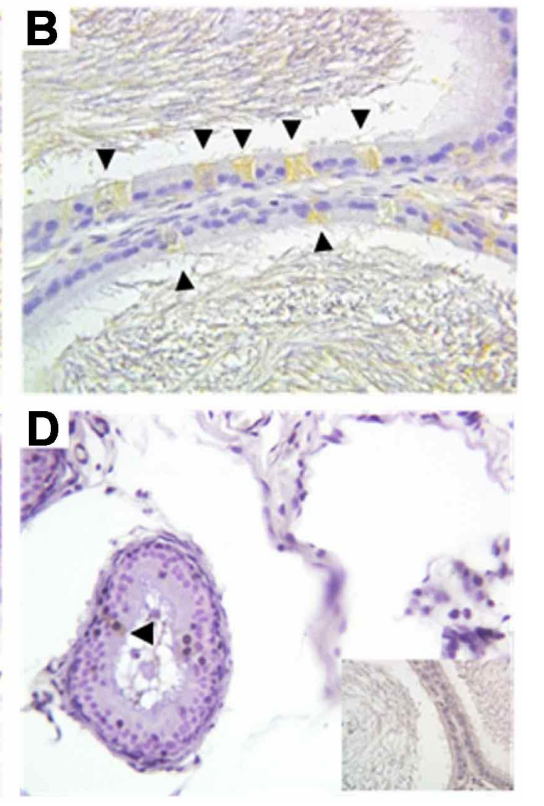

Fig. 4. Immunohistochemical staining of leptin after EDL procedure. Leptin staining is seen in both caput and cauda regions of EDL and contra-lateral sides (arrowhead). Tubules atrophy, increase of epithelial height and changes on cellular morphology were observed and could be related to the androgen deprivation that usually occurs after EDL. The insert shows negative control. Magnification X 200.
Figure 2d depicts the $\mathrm{OBRa} / \mathrm{OBRb}$ ratio in epididymis. In caput, the ratio is $77.3 \%$ and $22.6 \%$ and in cauda is $90.6 \%$ and $9.4 \%$ for OBRa and OBRb, respectively. Both epididymis regions have the predominance of OBRa gene expression but cauda has the total gene expression increased 1.6 times over caput region.

Figure 3 shows the immunohistochemistry results for leptin and OBR. Both leptin and OBR were detected on epididymal fluid and on epididymal epithelia of caput and cauda. Among the epididymal epithelial cells only clear cells were stained for both leptin and its receptor.

Efferent ducts ligation was performed to evaluate if the stain for leptin was due to clear cells leptin synthesis or if the hormone was being synthesized in the testis and carried through the luminal fluid. After EDL, clear cells continued to stain for leptin but in a low intensity compared to the contra lateral epididymis. There was no stain in the lumen. Reduction of lumen area, increased epithelial height and epithelial cell atrophy could be also observed in response to the androgen deprivation (Fig 4).

\section{DISCUSSION}

There are a few reports showing the presence of leptin and its receptors on epididymis and it is concerning pig and lizard models only (Putti et al., 2009; Rago et al., 2009). The authors believe that it is the first time that the presence of leptin 
and its receptors are shown on the different epididymis regions of rat.

Our results show that both epididymis regions, caput and cauda, express leptin and OBR. The western blot results showed that leptin is expressed only in the caput while OBR is expressed in both regions, although the expression of the leptin receptor was higher in the caput. The data from real time PCR shows that both regions are capable of leptin synthesis, which is higher in cauda. OBRa and OBRb were also expressed in both epididymis regions, the OBRa expression being higher in epididymis cauda. The ratio between OBRa/ OBRb shows that both regions are enriched by the leptin receptor short isoform, which have already been reported in other tissues (Fei et al., 1997). At this moment, we are unable to explain the reason for the fact that at protein level leptin and OBR are more expressed in the caput while at mRNA level both are more expressed in cauda region. It suggests that leptin may act in a region specific way, as has been described in reference to other proteins (Yuan et al., 2006).

It is known that spermatozoa formed in the testis will enter the epididymis caput, progress to corpus and finally reach the cauda region, where they are stored. During their transit, sperm undergo maturation processes necessary to acquire important functions. Because both epididymis regions express leptin and OBR at gene and protein levels, we could assume that this hormone may have a potential action on this organ in both spermatozoa and epithelial membrane. As leptin role on spermatozoa is still contradictory (Jope et al., 2003; Li, Chiu et al., 2009; LangeConsiglio et al., 2014) and we do not have enough information about its role on epididymis, further studies are necessary to establish in which epididymis functions leptin are involved.

Leptin and OBR were identified on epididymal fluid, spermatozoa and epididymis epithelia through immunohistochemistry technique. In relation to the epididymal epithelia, only clear cells were stained for both antibodies. This is a novel and interesting result suggesting that clear cells function could be regulated by leptin. The fact that clear cells are responsible for protein clearance (Cornwall) and are able to endocyte a high number of different proteins (Hermo et al., 1992; Vierula et al., 1995), which raises the hypothesis if the leptin detected through western blot and immunohistochemistry was a result of local synthesis or if they were taken up by the clear cells from the luminal fluid.

Trying to answer this question, an efferent duct ligation protocol was performed and leptin expression was evaluated by immunohistochemistry. Several morphological changes such as tubules atrophy, increase of epithelial height and changes on cellular morphology were observed and could be related to the androgen deprivation that usually occurs after EDL (Turner et al., 2007). Leptin stain was seen in both caput and cauda regions of EDL and contra-lateral side, although the contra-lateral side showed a more intense stain. This data suggest that the epididymis is able to produce the protein itself but in low concentration, raising the hypothesis that the highest amount of leptin on epididymis comes from testis and is uptaken by clear cells during the epididymal fluid transit. On the other hand, it is well known that most of testicular fluid is reabsorbed in the efferent ducts (Clulow et al., 1998), suggesting that leptin synthesis requires some testicular factors to be triggered, but we still have a lack of information to establish how leptin synthesis is regulates on epididymis.

\section{CONCLUSION}

Our results show that rat epididymis express both leptin and its receptors and the short isoform, OBRa, is more abundant in this organ compared to OBRb. Also, our data shows for the first time that leptin and OBR are expressed only in clear cells, which are able to produce the protein itself. On EDL group we observed a very low staining on CC suggesting that the highest amount of leptin is not locally produced, but uptaken from the fluid, possibly coming from testis or leptin synthesis demands some testicular factors to be produced. Further studies are necessary to establish the role of leptin in this organ.

\section{ACKNOWLEDGMENTS}

This work was supported by the agency FAPERJ (Rio de Janeiro State Foundation for Scientific Research, www.faperj.br) by the grant number E-26/1116.48/2011.

GOMBAR, M. F. \& RAMOS, FONTE C. La leptina y el receptor de leptina se expresan solamente en células claras del epitelio epididimario de rata. Int J. Morphol., 35(3):1303-1308, 2017.

RESUMEN: La leptina es una hormona de 16 kilodaltons secretada por el tejido adiposo y se ha relacionado en los últimos años con la regulación del sistema reproductivo. La leptina y su receptor (OBR) se han reportado en varios órganos reproductores y en diferentes especies sin embargo, en el epidídimo aún falta información. El objetivo de este trabajo fue establecer si la leptina y su receptor están presentes en el epidídimo y donde se produce. 
A nivel de ARNm la porción de cauda mostró una alta expresión de leptina ( $\mathrm{p}<0,025)$ y OBRa $(\mathrm{p}<0,002)$ mientras que a nivel de proteína la expresión de OBR fue menor en la región de la cauda epididimaria $(\mathrm{p}<0,025)$ y no se detectó leptina. La relación entre OBRa y OBRb fue mayor en ambas regiones a pesar de su cantidad total. Por inmunohistoquímica se detectaron leptina y OBR en el epitelio del epidídimo restringido a células claras (CC). Después de la ligadura del conducto deferente (EDL) se observó una disminución en la tinción de leptina en $\mathrm{CC}$, lo que sugiere que a pesar de la producción del epidídimo, la mayor parte de la fuente de leptina puede provenir probablemente del testículo. Nuestros resultados mostraron que la leptina y OBR, mRNA y proteína, están presentes en el epidídimo y exclusivamente en CC, lo que sugiere que este tejido es sensible a la hormona y puede tener un papel importante en la regulación CC.

PALABRAS ClAVE: Epidídimo; Célula clara; Leptina; OBR.

\section{REFERENCES}

Alves-Pereira, J. L.; Colli, S.; Marques, D. S.; Sampaio, F. J. \& Ramos, C. F. Molecular and morphometric analysis of the rat ventral prostate injected with leptin. Regul. Pept., 176(1-3):6-12, 2012.

Clulow, J.; Jones, R. C.; Hansen, L. A. \& Man, S. Y. Fluid and electrolyte reabsorption in the ductuli efferentes testis. J. Reprod. Fertil. Suppl., 53:1-14, 1998.

Cornwall, G. A. New insights into epididymal biology and function. Hum. Reprod. Update, 15(2):213-27, 2009.

da Silveira Cavalcante, F.; Gombar, F. M.; Ferreira, R. V.; da Silva Faria, T.; Costa, W. S.; Sampaio, F. J. \& da Fonte Ramos, C. Maternal proteinenergy and energy-restricted diets during lactation possibly could program folliculogenesis and the ovarian expression of leptin and its different isoform receptors in rats. Fertil. Steril., 92(5):1755-7, 2009.

Fei, H.; Okano, H. J.; Li, C.; Lee, G. H.; Zhao, C.; Darnell, R. \& Friedman, J. M. Anatomic localization of alternatively spliced leptin receptors $(\mathrm{Ob}-\mathrm{R})$ in mouse brain and other tissues. Proc. Natl. Acad. Sci. U. S. A., 94(13):7001-5, 1997.

Gombar, F. M. \& Ramos, C. F. Perinatal malnutrition programs gene expression of leptin receptors isoforms in testis and prostate of adult rats. Regul. Pept., 184:115-20, 2013.

Guo, J.; Zhao, Y.; Huang, W.; Hu, W.; Gu, J.; Chen, C.; Zhou, J.; Peng, Y.; Gong, M. \& Wang, Z. Sperm motility inversely correlates with seminal leptin levels in idiopathic asthenozoospermia. Int. J. Clin. Exp. Med., 7(10):3550-5, 2014

Havel, P. J. Role of adipose tissue in body-weight regulation: mechanisms regulating leptin production and energy balance. Proc. Nutr. Soc., 59(3):359-71, 2000.

Hermo, L.; Oko, R. \& Robaire, B. Epithelial cells of the epididymis show regional variations with respect to the secretion of endocytosis of immobilin as revealed by light and electron microscope immunocytochemistry. Anat. Rec., 232(2):202-20, 1992.

Jope, T.; Lammert, A.; Kratzsch, J.; Paasch, U. \& Glander, H. J. Leptin and leptin receptor in human seminal plasma and in human spermatozoa. Int. J. Androl., 26(6):335-41, 2003.

Lange-Consiglio, A.; Corradetti, B.; Perrini, C.; Bizzaro, D. \& Cremonesi, F. Leptin and leptin receptor are detectable in equine spermatozoa but are not involved in in vitro fertilisation. Reprod. Fertil. Dev., 28(5):57485, 2014.
Lee, N. P. \& Cheng, C. Y. Ectoplasmic specialization, a testis-specific cellcell actin-based adherens junction type: is this a potential target for male contraceptive development? Hum. Reprod. Update, 10(4):34969, 2004

Liu, X.; Liu, F. J.; Jin, S. H.; Shen, X. F. \& Wang, Y. W. In-depth Proteomic mapping of mouse (Mus musculus) epididymal constructive basis for sperm maturation. Proteome Sci., 13:20, 2015.

Palladino, M. A. \& Hinton, B. T. Expression of multiple gamma-glutamyl transpeptidase messenger ribonucleic acid transcripts in the adult rat epididymis is differentially regulated by androgens and testicular factors in a region-specific manner. Endocrinology, 135(3):1146-56, 1994.

Putti, R.; Varricchio, E.; Gay, F.; Elena, C. \& Paolucci, M. Leptin effects on testis and epididymis in the lizard Podarcis sicula, during summer regression. Gen. Comp. Endocrinol., 160(2):168-75, 2009.

Rago, V.; Aquila, S.; Guido, C. \& Carpino, A. Leptin and its receptor are expressed in the testis and in the epididymis of young and adult pigs. Anat. Rec. (Hoboken), 292(5):736-45, 2009.

Shum, W. W.; Ruan, Y. C.; Da Silva, N. \& Breton, S. Establishment of cellcell cross talk in the epididymis: control of luminal acidification. $J$. Androl., 32(6):576-86, 2011.

Tartaglia, L. A. The leptin receptor. J. Biol. Chem., 272(10):6093-6, 1997.

Tena-Sempere, M. \& Barreiro, M. L. Leptin in male reproduction: the testis paradigm. Mol. Cell. Endocrinol., 188(1-2):9-13, 2002.

Turner, T. T.; Johnston, D. S.; Finger, J. N. \& Jelinsky, S. A. Differential gene expression among the proximal segments of the rat epididymis is lost after efferent duct ligation. Biol. Reprod., 77(1):165-71, 2007.

Vierula, M. E.; Rankin, T. L. \& Orgebin-Crist, M. C. Electron microscopic immunolocalization of the 18 and 29 kilodalton secretory proteins in the mouse epididymis: Evidence for differential uptake by clear cells. Microsc. Res. Tech., 30(1):24-36, 1995.

Yuan, H.; Liu, A.; Zhang, L.; Zhou, H.; Wang, Y.; Zhang, H.; Wang, G.; Zeng, R.; Zhang, Y. \& Chen, Z. Proteomic profiling of regionalized proteins in rat epididymis indicates consistency between specialized distribution and protein functions. J. Proteome Res., 5(2):299-307, 2006.

Zhang, Y.; Proenca, R.; Maffei, M.; Barone, M.; Leopold, L. \& Friedman, J. M. Positional cloning of the mouse obese gene and its human homologue. Nature, 372(6505):425-32, 1994.

Corresponding author:

Cristiane da Fonte Ramos

Laboratório de Morfometria

Metabolismo e Doença Cardiovascular

Centro Biomédico, Instituto de Biologia

Universidade do Estado do Rio de Janeiro

Av 28 de Setembro 87

fds, 20551-030 Rio de Janeiro

BRAZIL

E-mail: cristiane@pesquisador.cnpq.br

Received: 20-06-2017

Accepted: 25-07-2017 